Warszawskie Studia Pastoralne UKSW

Rok XI 2016 Nr 3 (32)

MirosŁaw BiaŁous

(Warszawa)

\title{
ANGELOLOGIA DIONIZEGO AREOPAGITY W ŚWIETLE PISMA DE DIVINA HIERARCHIA
}

Angelology of Dionizy Areopagity in the Light of the Writing De Divina Hierarchy

Wybór tematu niniejszego artykułu nie jest dziełem przypadku, lecz ma na celu zwrócenie uwagi Odbiorców na zagadnienie mało obecne w teologicznej refleksji współczesnej. Zagadnienia dotyczące angelologii, pojawiające się w różnych religiach, nie tylko judeochrześcijańskiego pochodzenia, nie wydają się może dość łatwe do interesującej prezentacji, a może nie wykazując bezpośredniego związku $\mathrm{z}$ atakującym zewsząd strumieniem wiadomości i problemów, nie oferuje konkretnych rozwiązań przydatnych współczesnej realizacji prawd chrześcijańskiego życia, odwołując do niedostępnych ludzkiemu poznawaniu wyżyn niebiańskich.

Niniejszy artykuł również nie pretenduje do uznania go za nader interesujący a jego autor nie zamierza w zadowalający sposób wypełnić zarysowanej luki. Jego celem będzie raczej wskazanie na zręby bardzo interesującej koncepcji teologa chrześcijańskiego z szóstego wieku, który jako nie do końca określony pod względem swego pochodzenia czy biografii, może w jednakowej mierze być dla odbiorców Wschodu i Zachodu probierzem rozumienia spraw niebiańskich jako drogi do rozwiązania problemów ziemskich. Zarysowany

${ }^{1}$ W niniejszym artykule odwołuję się do odnośnych tytułów łacińskich, gdyż funkcjonują one w literaturze naukowej, łatwiej je też z technicznego punktu widzenia zamieścić w publikacjach. W polskim przekładzie stosuję też wariant Hierarchia niebiańska, a nie Boska (Divina) uznając jego przynależność do tradycyjnego ujęcia. 
dualistycznie kontrast pomoże w odnalezieniu drogi trzeciej, wiodącej do tej zasadniczej Prawdy, jaką dla każdego chrześcijanina są sprawy Boże, kwestie trynitarne.

\section{Autor nierozpoznany}

Mimo że zwłaszcza teologia zachodnia prezentuje autora omawianego dzieła jako Pseudo-Dionizego Areopagitę, autor artykułu idąc za tradycja prawosławną, wierną zarówno pełni prawdy jak i jej zrębom obecnym w legendzie, ośmielił się odrzucić pierwszy człon wartościujący, nie starając się jednak stawać w opozycji do wskazanych tendencji.

Fenomen Dionizego, o którym wspominają Dzieje Apostolskie ${ }^{2}$ wydaje się jednak być kluczem do zrozumienia teologicznego dzieła. Ustalenie bowiem środowiska, z jakiego się wywodził i w którym on działał pozwoli odnieść się także do prawd zawartych w traktacie. Przyjmijmy więc najpierw, iż autorem De divina hierarchia był współczesny św. Pawłowi z Tarsu Dionizy Ateńczyk.

Poznajemy go, gdy po nieudanym wystąpieniu Apostoła Narodów na ateńskiej agorze, wraz z niewiastą imieniem Damaris i kilkoma innymi osobami przyłączył się do Apostoła, bo uwierzył ${ }^{3}$.

Z pewnym zażenowaniem czytamy o tych zaledwie kilku osobach, które się nie poddały mądrym, lubującym się w ciągłych nowościach Ateńczycy, którzy tym razem uznali za słuszne nie poświęcać większej uwagi „jakiejś Anastazji”, o której rzekomo miał mówić Paweł"

Wskazanie na Dionizego i Damaris przez autora Dziejów nie jest przypadkowe: Dionizy odgrywał zapewne znaczną rolę w życiu polis, był więc człowiekiem powszechnie znanym. Przyznany mu przydomek Areopagity potwierdzać może taką właśnie sytuację. Z drugiej

${ }^{2} \mathrm{Dz} 17,34$

3 Tamże

4 Kiedy słuchacze „podchodzili do Apostoła, inni powątpiewali: I cóż to nam chce powiedzieć ten słowosiejca? Filozofowie im odpowiadali: Wydaje się być cudzoziemskich bogów głosicielem, bo wciąż mówi o jakimś Jezusie i Anastazji, a ma to być Dobra Nowina". (por. Dz 17, 18). Anastasia po grecku to Zmartwychwstanie... 
jednak strony przydomek ten mógł mieć znaczenie prześmiewcze: po reformach Solona i Peryklesa czas archontów Wzgórza Aresa (Areopagu) odszedł bowiem do przeszłości; czyżby więc chodziło o podkreślenie tendencji przywódczych (a może zwyczajnej wyniosłości lub zarozumiałości) tego, co go nosił?

Prawdopodobnie obie wersje są równouprawnione. Na pewno Dionizy był człowiekiem mocnym i świątobliwym, skoro został biskupem i męczennikiem, a potem niebiańskim patronem i obrońcą Aten, co potwierdza Euzebiusz z Cezarei.

Rzucone w ateńską ziemię ziarno Słowa wydało jednak plon...

Autor Hierarchii niebiańskiej sam zdaje się utożsamiać ze świątobliwym Ateńczykiem. W swych pismach nazywa Pawła nauczycielem (także swoim), swe listy adresuje do świętych biskupów Tymoteusza i Tytusa, a także do św. Jana Apostoła. Mówi, jakoby osobiście oglądał ciemności, jakie nastały po śmierci Zbawiciela...

Paralelna do wskazanej tradycja galijska w miejsce Areopagity umieszcza jedną z największych postaci wczesnych dziejów eklezjalnych, pierwszego biskupa Paryża, św. Dionizego (St. Denis), umęczonego na Górze Męczenników (Montmartre) między rokiem 250 a 253. Przyszły męczennik znalazł się na terenie Galii jako legat papieża Fabiana, mając za zadanie organizację struktur lokalnego Kościoła. Był to czas prześladowań, które dotknęły też Galię za czasów sprzyjającego arianizmowi cesarza Waleriana.

Jednakże ani o Dionizym Areopagicie, ani o świętym biskupie Paryża nie pozostało ani jedno, choćby krótkie dzieło. W związku z tym, choć omawiany traktat należy do zbioru Corpus Dionisiacum, autora przyjdzie nam szukać gdzie indziej.

Analizując jednakże domniemane autorstwo, na podstawie profilu psychologicznego obu Dionizych możemy uznać, iż autorem winien być człowiek postawiony na wysokim szczeblu hierarchii eklezjalnej, znający dobrze teologię, zarówno w wymiarze Starego, jak i Nowego Przymierza, człowiek doświadczony w dyskusjach apologetycznych, a zarazem doskonale zorientowany w całokształcie systemu teologicznego, który przecież ani w czasach Dionizego Areopagity, ani w czasach św. Dionizego z Paryża nie mógł zaistnieć... 


\section{Dzieło niedookreślone}

Powyższe rozważania odnośnie do autora mogą wywołać poczucie zawodu: gdybyśmy bowiem mogli z pewnością przyjąć, czy autorem jest biblijny bohater czy biskup - męczennik operowalibyśmy w tym samym przedziale czasowym II-III wieku. Jednakże nawet analiza językowa dzieła na takie wnioski nie pozwala. Język Hierarchii niebiańskiej nosi wyraźne znamiona greki średniowiecznej, co w jeszcze większym stopniu odnosi się do wersji łacińskiej dzieła. Dodatkowym problemem jest też milieu jego powstania: Dionizy z Areopagu należy bez wątpienia do kultury greckiej, podczas gdy Święty Paryżanin do łacińskiej. Co prawda, nawet domniemane odwołania do obu postaci mogą nam nasunąć wniosek, iż jest to dzieło z pogranicza, należące w jednakowej mierze do świata zachodniego, jak i wschodniego.

Jednak, jak wykazano, jego analiza nie rozwiązuje problemu autorstwa. Rozbudowany kontekst teologiczny z pewnością przesuwa datę jego powstania na czas późniejszy, niż doba prześladowań, a nazwa Corpus Dionisiacum, czyli Dzieła [przypisywane Dionizemu] ${ }^{5}$ każą też poszukiwać rozwiązania trzeciego.

Problemem zasadniczym jest jednak fakt, iż omawiane dzieło po raz pierwszy wzmiankowane jest dopiero przez Jana Gramatyka z Cezarei oraz w dziełach Sewera z Antiochii, dwu adwersarzy teologicznych z szóstego stulecia. Jan bronił Soboru Chalcedońskiego, podczas gdy Sewer, jako zagorzały monofizyta, stanowczo mu się sprzeciwiał. Datę powstania może sugerować też wzmianka z trzeciego rozdziału innego, wchodzącego w skład omawianego Corpus traktatu, mianowicie De Hierarchia Ecclesiastica, gdzie w opisie liturgii spotykamy Credo, wprowadzone do liturgii antiocheńskiej w V wieku. A zatem całe Corpus powstać mogło w połowie wieku VI.

$\mathrm{Z}$ postacią Pseudo-Dionizego wiązano też często w przeszłości anonimowego teologa bizantyjskiego, działającego na terenie Synaju (Egipt) w V bądź VI stuleciu. Przyjmuje się też, iż chodzi

${ }^{5}$ Gdyby były to dzieła św. Dionizego, wówczas zgodnie z regułami łaciny także średniowiecznej mielibyśmy tytuł Corpus Sanctii Dionisii na podobieństwo Corpus Cassiani czy Corpus Petri. 
o neoplatończyka działającego w Syrii. Jednocześnie obaj wskazani mniemani autorzy reprezentowali związki ze średniowieczną scholastyką. To właśnie tematyka zbioru sprawiła, iż na bazie wielkiego poruszenia mentalnego $\mathrm{w}$ roku $532^{6}$ zorganizowano dyskusję religijną, na której Corpus uznano za równe w autorytecie Pismu Świętemu i jako takie zaczęto propagować. Egzemplarz dzieła pojawił się też na gruncie galijskim, gdzie w paryskim opactwie św. Dionizego przetłumaczono pełny jego tekst na łacinę.

Niezależnie jednak od tego, kogo uzna się za autora, niezależnie od tego, śladem jakiej legendy się podąży, Corpus Dionisiacum jest zbiorem dziel autentycznych, mających duże znaczenie dla pierwszego okresu średniowiecza i nie tylko. Istotną bowiem sprawą był treściowy ich zakres, dzięki któremu zyskiwały one rangę niemal apokryficzną.

A w owym czasie, zarówno po stronie wschodniej, jak i zachodniej (Ambroży z Mediolanu, po nim bł. Augustyn czy św. Grzegorz Teolog), swe apogeum rozwojowe osiągała angelologia. Tak rozpoczęła się średniowieczna sława dzieła, które chyba niesłusznie uległo zapomnieniu.

A było to dzieło, które nie da się do końca zdefiniować, dzieło które wywodząc się ze Wschodu, na Zachodzie zyskuje uznanie.

\section{Słowo kluczowe: hierarchia}

Zarówno w języku łacińskim, jak i w językach nowożytnych, trudno ustalić jednoznaczna semantykę tego kluczowego słowa. A przecież od jego rozumienia zależy mentalne rozpoznanie całego traktatu!

W języku polskim słowo to znalazło swe miejsce za pośrednictwem języka starofrancuskiego i łaciny średniowiecznej, aczkolwiek jego etymologia nawiązuje do greki wczesno klasycznej. Hieros - święty, uświęcony, uznany za wywyższony ${ }^{7} \mathrm{i}$ arché mająca w języku greckim co prawda około 60 znaczeń, lecz za najważniejsze z nich uchodzi zasada bytu, jego trwanie i istnienie. Derywat -archia (archeja) odnosi

\footnotetext{
${ }^{6}$ W kontekście przygotowań do Soboru Konstantynopolitańskiego II.
}

7 Stąd hieroglify - sakralne znaki [wyryte na twardym podłożu]. 
się do sposobu realizacji tego trwania i tego istnienia ${ }^{8}$. Jako reprezentant sacrum (hieros), staje się hierarchia czymś dogmatycznie niepodważalnym, bez czego żadna społeczność istnieć by nie mogła.

Do czego jednak się odnosi zróżnicowanie hierarchiczne? Zapewne racje mają jedni, co wiążą ją z władzą, rację mają także drudzy, wykazujący jej powiązanie z zakresem powinności i odpowiedzialności. W każdym przypadku jest hierarchia określonym zróżnicowaniem i określonym zakresem?.

W ten sposób istniejąca na bazie hierarchii struktura społeczeństwa czy grupy staje się konglomeratem zakresu powinności i ograniczeń zarówno w aspekcie sposobu, jak i pól ich realizacji. Można się odwołać do powszechnie znanego hasła liberalizmu: Wolność jednego kończy się tam, gdzie zaczyna wolność drugiego, a sprawa odpowiedzialności dotyczy w jednakowej mierze odpowiedzialność za realizację własnych zakresów i zróżnicowań, jak i zakresów i zróżnicowań drugich.

Czy jednak hierarchia jest czymś uświęconym, czymś w rodzaju fetyszu? Święta hierarchia dostojników różnych społeczności wierzących, wydaje się potwierdzać taki stan rzeczy, jednakże naturalne pochodzenie tej kategorii potwierdzają nawet analizy bytowania stadnego, zwłaszcza w odniesieniu do tzw. „zwierząt wyższych” - ptaków, a zwłaszcza ssaków:

Na czele stada funkcjonuje zawsze jednostka, ciesząca się określonymi przywilejami, lecz i obarczona obowiązkami.

To bocian lecący na czele wyznacza kierunek zimowego odlotu, to przewodnik stada wyprowadza je z największej nawet obierzy.

Hierarchia, mimo swego naturalnego pochodzenia, postrzegana jest jednak zasadniczo przez pryzmat Kościołów czy związków

${ }^{8}$ Niektórzy hierarchię utożsamiają z władzą i jej stopniami - hierarchizacja społeczeństwa to zarazem hierarchizacja stopni władzy w porządku malejącym -ci, co najwyżej, mają władze praktycznie nieograniczoną, ci, co najniżej - niemal żadną.

9 Zróżnicowanie dotyczy stopni różnorodnych zobowiązań, zakres zaś określa granice nie tylko pomiędzy tymi zobowiązaniami, lecz także umiejscowieniem w systemie hierarchicznym. 
wyznaniowych. Z uwagi na argument naturalny możemy powiedzieć, iż wskazane zróżnicowanie jest uświęcone konsekracją świata, wyrazem szczególnego orzeczenia i wywyższenia Bożego: bogami jesteście i synami Najwyższego wy wszyscy (Ps 82,6). Dzięki takiemu orzeczeniu potwierdza się szczególne miejsce człowieka, a za jego pośrednictwem także Eklezji w procesie leczenie ran serc złamanych, zwiastowania ubogim Dobrej Nowiny, uzdrawiania itp. (por. Iz 61,1). Dzięki takiemu orzeczeniu ludzie nazwani są przyjaciółmi Boga ${ }^{10}$ !

W kontekście naturalnie pojmowanej hierarchiczności społeczność Boża jawi się jako miejsce spotkania dwóch podmiotowych egzystencji: Boga i osoby, które w niezwykłym dialogu, istocie relacji międzyosobowych, dokonują odsłonięcia własnych „wnętrz”, co jest swoistym przekazem treści egzystencjalnych (ze strony człowieka), zbawczych ze strony Boga ${ }^{11}$.

Zhierarchizowana rzeczywistość eklezjalna miała jednoznaczny wpływ na recepcję hierarchii niebiańskiej. Bardzo często, zwłaszcza w dobie Średniowiecza, pokazywano hierarchię kościelna jako odbicie hierarchii Nieba, a życie społeczności wierzących zrównywano z niebiańskimi doświadczeniami Aniołów. Uznając ten układ za doskonały powtarzano, iż hierarchiczność uświęcona jest podwójnie, stąd przywileje dla stojących najwyżej osiągnęły z czasem wymiar dogmatyczny...

Jak ludzie w społeczności, od aniołów niewiele mniejsi, tak i Aniołowie, bezpośrednio trwający przed Bogiem ze względu na Niego samego poddani są takim samym prawom, jakie rządzą Eklezją, społecznością wezwanych. A zatem Bóg stoi na początku zhierarchizowania, Bóg jest jego istotnym Odbiorcą i Kryterium.

A gdzie Bóg, tam i Niebo.

\section{Patrząc oczyma Pseudo-Dionizego...}

Przystępując do zasadniczej problematyki niniejszego artykułu warto zauważyć, iż koncepcja hierarchiczna Dionizego została oficjalnie

10 Św. Cyryl Aleksandryjski, Komentarz na Izajasza,L II. 1.

11 Tamże, s. 21. 
zauważona i uznana przez Sobór Konstantynopolitański II (553 r.), zwłaszcza że paralelnie rozpatrywana przez ojców tego soboru koncepcja Orygenesa, zakładająca równość wszystkich bytów anielskich, została odrzucona.

Hierarchiczna prezentacja życia niebiańskiego miała swe odwzorowanie w hierarchiczności eklezjalnej, stąd nic dziwnego, że innym dziełem, wchodzącym w skład Corpus Dionisiacum był traktat De hierarchia ecclesiastica.

Zestawienie tych dwu koncepcji - niebiańskiej i eklezjologicznej stanowiło przez tysiąc lat Średniowiecza zasadniczy kierunek katechetyczno-homiletyczny. Można powiedzieć, iż zarówno na Wschodzie, jak i na Zachodzie omawianą koncepcję uznano za jedynie poprawną dogmatycznie i dlatego ja rozpowszechniano, chętnie powołując się na biblijnego bohatera z Areopagu, co dawało asumpt do traktowania jej jako najstarsze, od samego Apostoła się wywodzące przedstawienie problemu.

Zasadniczy podział hierarchiczny bytów anielskich dokonuje się w triadzie, stanowiącej każda z nich triadę oddzielną. Symbolika takiego podejścia nie jest przypadkowa: jeżeli uznamy Aniołów za stworzenia Boga, posługujące jednak w bezpośredniej z Nim styczności, nie możemy pominąć ich odniesień do bytowania trynitarnego. Można zatem uznać, iż koncepcja ta potwierdza również podejście starotestamentalne, gdy aniołowie działając w odniesieniu do ludzi potrafili „zastąpić Boga”, przybierając postać człowieka i wchodząc z nim w niezwykły dialog.

Na szczycie wskazanego podziału hierarchicznego spotyka się Serafinów, Cherubinów i Trony; triadę druga tworzą Panowania, Moce i Władze ${ }^{12}$, a trzecią Zwierzchności, Archaniołowie i Aniołowie. Stosując odwołania skrypturystyczne możemy uznać, iż triada

\footnotetext{
12 Na marginesie koncepcji Dionizego zauważyć wypada, iż wskazana druga triada u św. Pawła $(K o l 1,16)$ jest poszerzona o Trony. Zarówno one, jak Panowania, Zwierzchności czy Władze stworzone są przez Chrystusa i dla Niego. Dlatego, zdaje się mówić Apostoł Narodów, niezależnie od miejsca w hierarchii anielskiej, Chrystus pozostaje większym od Aniołów i centrum ich odniesienia.
} 
pierwsza uwielbia Boga, triada druga reprezentuje Moc Bożą, a trzecia wchodzi w relacje z człowiekiem. Inaczej mówiąc, mamy do czynienia z Uwielbieniem, Pośrednictwem i Wykonaniem.

Pierwszą hierarchię zajmują wszystkie duchy natury wyższej, których stanowisko jest tuż przy ich Stwórcy. Są to duchy najczystsze w sensie ich natury, życiem których jest kontemplacja Trzech Boskich Hipostaz. Ich umiejętnością wyjaśnianie symboli i łączność z Bogiem, Który jest Dawcą wiedzy, Tym, co ich oświeca ${ }^{13}$. Oświecenie to przekazują duchom niżej od siebie stojącym, a jest to wiedza o groźnym Majestacie, godnym z twego powodu wszelkiego uwielbienia ${ }^{14}$.

Trójstopniowe uwielbienie Boga triady pierwszej wyraża się w hymnie Trishagion (Święty, Święty, Święty), śpiewanym przez Serafinów ${ }^{15}$, którzy w ten sposób odsłaniają Tajemnicę istoty Bożej - Najwyższą Świętość będącą wyrazem najwyższej Miłości. Ich atrybutem są trzy pary skrzydeł, których używają do latania wokół Tronu Boga i wyrażania najwyższej pokory poprzez okrywanie swego ciała. Są one wypełnione szczególnym żarem miłości i szczególnym oddaniem Najwyższemu, w związku z tym jako w szczególny sposób przyzwyczajeni do rzeczy Bożych pełnią oni posługę światła, dzięki czemu rozproszeniu ulegają wszelkie ciemności ${ }^{16}$. Jak się wydaje, Serafini nie byli posłańcami, gdyż ich widok zbyt straszny jest dla ludzkiego oka ${ }^{17}$.

Podobnie rzecz się miała z Cherubinami bądź Cherubami. Ich wygląd nie pozwala na oglądanie ich przez człowieka ${ }^{18}$, lecz zapewne z tego powodu, iż są one zbyt piękne. Odwołując się do wizji anielskiej proroka Ezechiela Dionizy wskazuje, iż podtrzymują one Tron Boży,

\footnotetext{
13 Niezależnie od wyznania, także w judaizmie głównym atrybutem aniołów jest inteligencja, która nie zanikła też u aniołów upadłych...

14 Por. Dionizy Areopagita, O hierarchii niebiańskiej, przekł. E. Bułhaka, Kraków 1932, s. 146.

15 Por. $I z$ 6,1; wizja sześcioskrzydłych serafinów stanowi początek prorockiego powołania.

16 Por. Dionizy, O hierarchii, s. 141.

17 Por. H. Oleszko, Anielska Hierarchia Dionizego Areopagity [wersja internetowa]

18 Czego odzwierciedleniem może być opis wygnania ludzi z raju ( $R d z 3,23-24)$
} 
kontemplując Najwyższe Piękno. Ich wygląd podobny jest do człowieka: mają po cztery twarze i po cztery skrzydła. Nogi ich są proste, stopy zaś podobne do stóp cielca, lśniące jak brąz czysto wygładzony. Po czterech bokach miały skrzydła, a pod nimi ręce ludzkie. Twarze ich dysponowały czterema obliczami: ludzkim, lwim, obliczem wołu i obliczem orła, a one same poruszały się zawsze prosto, nie odwracając się nigdy ${ }^{19}$.

Nazwa Cherubinów oznacza „dar poznania i uwielbiania Boga, oglądanie światła w Jego pierwotnym blasku i piękna niestworzonego $\mathrm{w}$ jego najwspanialszym promieniowaniu ${ }^{20}$.

Trony to gorejąca potęga ognia, nieustannie zakotwiczona przy Tronie Boga, Stwórcy wszystkiego, do czego zresztą odwołuje się ich imię. Ich szlachetność każe pozostawić za sobą wszystko, co niskie i upadłe, co przeszkadza w permanentnym zjednoczeniu z Panem. Są oni żądni nieustannych nawiedzin Boskości, a choć drżą przed obcowaniem z Nią, przecież gorąco jej pragną ${ }^{21}$. Pragnąc zaś, wchodzą w szczególne relacje, pozwalające na przekazanie im wszelkich tajemnic Boga.

Odnośnie do hierarchii drugiej Dionizy określa ich „powinności” kierując się głównie nazwami poszczególnych chórów. Ogólnie mówiąc, triada ta odwołuje się do Opatrzności Bożej, obejmującej bez wyjątku całe stworzenie.

Panowania przypominają powagę ich autorytetu „i ten piękny ordynek, w którym poddają się one wpływowi boskiemu"22.

Imię Zwierzchności oznacza przewyższanie wszelkich materialnych uwarunkowań, a zatem najwyższe uduchowienie, dzięki któremu mogą one trwać w doskonałym porządku i harmonii, ulegając

\footnotetext{
19 Opis Cherubów Ez 1, 4-11. Warto też zwrócić uwagę, iż ich wyobrażenia na Arce Przymierza Świątyni Jerozolimskiej potwierdzały obecność Bożą, trwającą pomiędzy ich złączonymi skrzydłami. Por. H. Oleszko, art. cyt.,

20 Dionizy, O hierarchii, s. 141-142.

21 Tamże, s. 142.

22 Tamże, s. 120.
} 
Bożemu wpływowi, by ich autorytet nie został splamiony żadną namiętnością.

Władze, jak podkreśla Dionizy, odwołują się do „męskiej, niezwyciężonej energii" ${ }^{23}$, która podtrzymuje ich w spełnianiu funkcji.

Prezentacja bardziej szczegółowa pozwala stwierdzić, iż pośrednictwo, przypisywane jako atrybut drugiej hierarchii wypełniane jest w Mocy Bożej z mocą istot niebiańskich. Jest to szczególnie ważne dla człowieka, bo za pośrednictwem Aniołów ma pewność nieustannej opatrznościowej opieki.

Aniołowie $\mathrm{z}$ hierarchii trzeciej wykonują Boże polecenia, poddając się Jego rozkazom, zgodnie z porządkiem właściwym dla sił wyższych $^{24}$. Koncentrują one swą uwagę szczególnie na Archaniołach, z uwagi na ich „oddalenie” od Bożego oddziaływania. Dzięki temu uporządkowaniu wewnętrznemu zgodna $\mathrm{z}$ anielska naturą godność wysłańca może być realizowana w zgodzie z Wolą Bożą, którą za swym pośrednictwem przekazują całej ludzkości.

W przedstawionej powyżej refleksji angelologicznej na pierwszy plan zdaje się wybijać termin „porządek”, „uporządkowanie”. W uporządkowaniu tym zawiera się pewna hierarchizacja. Oto jak ją przedstawia autor: „Każdy poszczególny porządek aniołów jest tłumaczem i zwiastunem wyższego od niego porządku. Pierwsi roznoszą rozkazy bezpośrednie Bóstwa, a drudzy otrzymują je, aby przekazać tym, co po nich następują" ${ }^{25}$.

Dzięki uporządkowaniu i określonej jakości podporządkowania, Autor omawianego dzieła hierarchię niebiańską postrzega jako "naukę i jako działalność". Aniołowie stosując się o ile możności do właściwości boskich odtwarzają przez swoje blaski wyobrażenie rzeczy znajdujących się w Bogu"26.

W przedstawionym powyżej sformułowaniu możemy znaleźć odniesienia do prawdopodobnie współczesnej autorowi koncepcji

23 Dionizy, O hierarchii, s. 147.

${ }^{24}$ Por. tamże, s. 150.

25 Tamże, s. 154.

26 Tamże, s. 132. 
papieża Grzegorza Teologa, postrzegającego Aniołów dwuaspektowo: jako przekazujących wieść (stąd Angelus nie jest imieniem własnym, jeno funkcją) i jako ukierunkowanie w stronę ludzi (działanie, exemplum Aniołowie Stróżowie). Bezpośrednie uczestnictwo w niebiańskiej rzeczywistości Boga każe im nieustannie się w Niego wpatrywać i upodabniać, a w ten sposób niejako przybliżać rzeczywistość teologalną antropologicznemu wymiarowi życia.

Takie zastrzeżenie wydaje się niezbędne, gdyż nieco dalej pada bardziej „scholastycznie” ujęta definicja hierarchii: jest to „pewien układ i porządek święty, odbicie piękności niestworzonej, która spełnia w swej własnej sferze, zależnie od możności i znajomości, jakie jest jej udziałem i stara się upodobnić do swojej zasady pierwotnej"27 $\mathrm{w}$ celu upodobnienia się i zjednoczenia $\mathrm{z}$ Bogiem $^{28}$.

Hierarchiczność życia niebiańskiego pojmowana jako zjednoczenie z Bogiem powoduje niezwykły dynamizm i ożywienie każdego istniejącego w Bogu stworzenia: stworzenia te mogą się oczyszczać, jeszcze bardziej udoskonalać, czyli każdy na swój sposób naśladować Boga.

Zwróćmy uwagę, iż w zaprezentowanym przez autora „schemacie hierarchicznym” niezwykłą rolę odgrywa dynamizm życia w Bogu, dynamizm udzielany innym stworzeniom. Jednocześnie nie spotykamy tu lansowanej przez przekaz homiletyczno-katechetyczny faktu doskonałości osoby wchodzącej do uczestnictwa niebiańskiego. Rzeczywistość udoskonalania zakłada istnienie wcześniejszej niedoskonałości i odpowiedni dla każdej osoby kształt jej bytowania. Osiąganie Bożej doskonałości i absolutnej czystości, czyli wywyższenie natury, ma swój aspekt „formalny”: gdy ktoś na ziemi był człowiekiem, jako człowiek realizuje swą wieczność, jeżeli jest Aniołem, czyni to jako Anioł.

Zatem nie tylko doskonałość Boga powoduje swoiste „rozwarstwienie”, lecz także natura uczestnika życia wiecznego. Każdemu zresztą,

\footnotetext{
Tamże, s. 133.
}

28 Por. tamże. 
dodajmy, dana jest Łaska podług jego miary, a miara ta porządkuje realizację procesu zbawczego.

Koncepcja autora Hierarchii osadzona jest na pogłębionej analizie skrypturystycznej. Nie brak tu „przestrzennego” pojmowania nieba, charakterystycznego zresztą zwłaszcza dla Starego Testamentu, stąd principium hierarchiczności niebiańskiej zasadza się na „większej” lub „mniejszej” odległości od Boga. Hierarchiczny świat opisywany przez Dionizego jest doskonały, piękny i niezwykle barwny, obfitujący w elementy kosmologiczne ${ }^{29}$. Tu wszystko dojrzewa do swojej własnej pełni.

Zasadniczym punktem odniesienia były wizje proroka Izajasza i uwagi o aniołach zawartych w listach św. Pawła ${ }^{30}$. Z tego względu zasadniczą cechą tej koncepcji jest jej chrystocentryzm, gdyż Chrystus jest Panem wszelkiego stworzenia z uwagi na Swą obecność w działaniu kreacjonistycznym, jest Tym, co osobiście nawiedził wszelkie wymiary egzystencji: nie przestając przebywać w Niebie przybył na Ziemię i odwiedził Otchłań.

Jak się wydaje, obraz Dionizego wykazuje też analogie z obrazem Edenu. Przed grzechem pierwsi ludzie byli „blisko”, a Bóg się z nimi przechadzał po ogrodzie, by po grzechu stać się „dalekimi”, a Bóg stawiał przed bramą Raju cheruby z ognistymi mieczami. Podobnie jednak, jak w przekazie Poematu Stworzenia czy bardziej precyzyjnie, poematu rodzaju ludzkiego, zarówno bliskość jak i dal są pojęciami umownymi, mającymi wskazać relację, nie zaś usytuowanie. W takim też sensie warto rozumieć traktacie hierarchię anielską.

\section{Zakończenie}

Z dzisiejszej perspektywy przedstawione powyżej wczesnośredniowieczne próby klasyfikacji nie wydają się już tak przekonujące, jak dawniej. Wtedy bowiem, gdy obowiązywało inne postrzeganie

\footnotetext{
29 Por. H. Oleszko, artykuł cytowany

30 Powiązanie z Apostołem Narodów wydaje się bardzo naturalne z uwagi na postać Dionizego Areopagity z Dziejów Apostolskich.
} 
kosmosu, inna wizja zewnętrznego świata, także Aniołowie pełnili role swoistych demiurgów, poruszycieli, zwiastunów...

Nie wiemy, bo Pismo Święte nie prezentuje tej sprawy dokładnie, ile jest chórów anielskich. Nie wiemy, bo wiedzieć nie możemy, (a w wymiarze soteriologicznym nie musimy), jaka jest ich organizacja. Także współczesny kult aniołów niewspółmierny jest średniowiecznemu.

Warto jednak zapoznać się z anonimową koncepcja autora $\mathrm{z}$ VI stulecia. Jego dzieła, o treści których ledwie tu wspomniano, warte są pogłębionej lektury. Bo wszystkie tytuły wchodzące w skład Corpus Dionisiacum to dzieła genialne. Bo każde z nich nieodparcie pobudza do fascynacji tym, czego ani oko nie widziało, ani ucho nie słyszało, ani w serce człowieka nie wstąpiło, co Pan przygotował wybranym Swoim ${ }^{31}$.

\section{Streszczenie:}

Artykuł dotyczy najpopularniejszej koncepcji angelologicznej, która istniała w świadomości teologicznej dla całej epoki średniowiecznej. Koncepcja ta była ważna nawet w okresie Soboru Watykańskiego z powodu jej aktualność i wierności obrazu biblijnego świata aniołów.

\section{Summary:}

This article above refers the most popular conception of Angelology which has been presented in theological consciousness for whole medieval epoch. This conception was important even at the Vatican Council period because of her actuality and fidelity to the biblical image of the Angels' world. Such a situation seems to be a little strange after all, because real Dionysius (or Saint Denis) have written no theological book and has prepared no one theological conception, so the Author is simply unknown. In fact, even legendary connexions with the first St Paul's Athenian pupil permitted the conception become more important in the Orthodox Theology so far not established Dionysius' from Paris authorship opened the door to Occidental theological mind. In fact, presented conception seems to be very actual from

\footnotetext{
31 Por. 1 Kor 2,9;
} 
ecumenical point of view, because there are different theological elements from the West, Occident and even from Judaism in herself.

Słowa kluczowe: Teologia, Prawosławie, Angelologia, Hierarchiczność.

Keywords: Theology, Orthodox, Angelology, Hierarchy

\section{Biogram:}

dr Mirosław Białous, urodził się 2 marca 1977 r. w Białej Podlaskiej, magister teologii w Chrześcijańskiej Akademii Teologicznej w Warszawie, doktor historii i nauk społecznych Uniwersytetu Kardynała Stefana Wyszyńskiego w Warszawie. Autor wielu artykułów z zakresu teologii i historii Kościoła. Zainteresowania: zagadnienia z zakresu teologii, historii, archeologii, etnologii i antropologii kulturowej. Od 2002 r. kustosz zabytkowego Cmentarza Prawosławnego na Woli w Warszawie.

\section{Bibliografia:}

Dionizy Areopagita, O hierarchii kościelnej, przekł. E. Bułhaka, Kraków 1932;

Dionizy Areopagita, O hierarchii niebiańskiej [w:] Pseudo-Dionizy Areopagita, Pisma teologiczna, tłum. M. Dzielska, t. II, Kraków 1999, s. 45-114;

Dionizy Areopagita,O hierarchii niebiańskiej, przekł. E. Bułhak, Kraków 1932;

Dzielska M., Porządek anielski w Hierarchii niebiańskiej Pseudo-Dionizego Areopagity, [w:] Księga o aniołach pod red. H. Oleszko, Kraków 2002, s. 122-130;

Korczyński M., ks., Teologia kosmiczna w pismach Pseudo-Dionizego Areopagity, Radom 1997;

Oleszko H., Anielska Hierarchia Dionizego Areopagity [artykuł, wersja internetowa]

O Duchu Świętym, tłum. i opracowanie Alina Brzóstkowska, wstęp ks. J Naumowicz, Warszawa 1999, s.135. 